\title{
Penerapan Model Student Teams Achievement Divisions (STAD) dan Think Pair Square (TPS) Untuk Meningkatkan Ketrampilan Berbicara dan Menulis Bahasa Arab Pada Siswa Kelas X SMA Terpadu Al-Ma'shum Mardiyah Cianjur

\author{
Dede Muharamsyah*, Soewarto Hardhienata**, M Entang** \\ * Mahasiswa Program Studi Administrasi Pendidikan, Program Pascasarjana \\ ** Staf Dosen Manajemen Pendidikan, Program Pascsarjana \\ Universitas Pakuan \\ Bogor, Indonesia
}

Diterima: 5 Oktober 2015. Disetujui: 1 November 2015. Dipublikasikan: Januari 2016

\begin{abstract}
Abstrak
Penelitian ini merupakan Penelitian Tindakan Kelas (PTK). Tujuan dari penelitian ini adalah untuk meningkatkan hasil belajar siswa dalam bahasa Arab terutama keterampilan al-Kalam dan al-Kitabah dengan menerapkan model pembelajaran STAD dan TPS. Subject penelitian ini adalah siswa kelas X.3 SMA Terpadu al-Ma'shum Mardiyah Cianjur yang berjumlah 22 siswa yang terdiri dari 11 siswa perempuan dan 11 siswa laki-laki. Keterampilan alKalam dan al-Kitabah adalah dua keterampilan dari empat keterampilan berbahasa yang harus dikuasai oleh siswa dalam mempelajari bahasa Arab sebagai bahasa asing. Meski demikian, hasil penelitian awal yang dilaksanakan pada semester ganjil tahun pelajaran 2014-2015 menunjukkan bahwa nilai rata-rata kemampuan siswa dalam keterampilan al-Kalam dan al-Kitabah masih rendah dari Kriteria Ketuntasan Minimal (KKM). Peningkatan nilai rata-rata dari siklus pertama adalah $68,2 \%$ menjadi $72,7 \%$ untuk nilai al-Kalam, dan $77,3 \%$ menjadi $81,8 \%$ untuk nilai al-Kitabah. Disamping itu siswa kelihatan aktif dan bersemangat dalam proses belajar mengajar dengan menggunakan model pembelajaran STAD dan TPS. Pencapaian nilai tersebut diperoleh setelah dilakukannya penelitian tindakan kelas dengan melalui proses 4 langkah, yaitu perencanaan, pelaksanaan, observasi, dan refleksi. Penelitian ini dilaksanakan dalam dua siklus. Siklus satu dan dua masing-masing terdiri dari tiga pertemuan. Data penelitian dikumpulkan melalui beberapa instrumen yaitu lembar observasi, catatan lapangan, kuisioner dan penilaian akhir siswa. Berdasarkan hasil penelitian, saran ditujukan kepada para guru bahasa Arab yang mempunyai masalah yang sama agar mengimplementasikan kedua model pembelajaran STAD dan TPS untuk meningkatkan kemampuan berbahasa Arab terutama dalam keterampilan al-Kalam dan al-Kitabah, untuk peneliti yang akan datang dianjurkan untuk mengadakan penelitian secara mendalam untuk meningkatkan hasil belajar siswa.
\end{abstract}

(C) 2016 Program Pascasarjana Universitas Pakuan

KATA KUNCl: Student Teams Achievement Divison, Think Pair Share, Keterampilan Berbicara dan Menulis

\section{PENDAHULUAN}

Bahasa dan manusia adalah dua hal yang tidak dapat dipisahkan, dalam bahasa arab dikatakan bahwa manusia itu hayawaanun nathiq (makhluk berbicara). Sebagai makhluk sosial, manusia membutuhkan media dalam berinteraksi antar satu dengan lainnya dan bahasa merupakan media interaksi utama dalam 
mengkomunikasikan setiap kebutuhan dan keinginan yang bergantung kepada manusia lainnya.

Oleh karena bahasa merupakan media komunikasi antar manusia, maka karakter dan jenis bahasa sangat ditentukan oleh kondisi, situasi, tempat dan zaman dimana manusia itu berada. Bahasa orang Inggris tentu berbeda dengan bahasa orang Arab karena kedua bangsa ini berbeda wilayah, cuaca, budaya, dan kebutuhan sehari-hari masyarakatnya.

Dari sekitar 6.912 bahasa yang ada saat ini, terdapat beberapa bahasa yang secara internasional digunakan sebagai media komunikasi global, Bahasa Inggris merupakan bahasa utama internasional karena banyaknya negara pengguna bahasa ini selain didukung oleh banyaknya wilayah jajahan Inggris yang kemudian menjadikan bahasa Inggris menjadi bahasa ibu Negara tersebut, dan badan Perserikatan BangsaBangsa menjadikannya sebagai bahasa resmi dalam setiap sidang dan kegiatan lobi internasional.

Demikian juga bahasa Arab, dapat digolongkan ke dalam bahasa Internasional karena ada sekitar 29 negara yang menggunakan bahasa Arab sebagai bahasa negaranya, maka PBB pun menjadikan bahasa ini sebagai bahasa resmi dunia, demikian pentingnya bahasa Arab dalam percaturan hubungan internasional. Terlebih jika dikaitkan dengan kegunaan bahasa Arab dalam kehidupan sehari-hari umat manusia, dimana umat muslim di dunia ini menjadi umat terbesar kedua setelah Kritisani, ada sekitar 2 milyar umat muslim, yang pasti menggunakan bahasa Arab dalam kegiatan ritual ibadah mereka terutama ibadah shalat, karena tidak diperkenankan menggunakan bahasa lain dalam bacaan shalat, demikian juga dalam ibadah mahdhoh lainnya yang harus perpola kepada contoh dan perintah Rasulullah saw. Pun demikian bagi kita yang tinggal di Indonesia, umat muslim menjadi umat terbesar, maka sudah sangatlah wajar jika bahasa Arab menjadi kebutuhan yang tak terelakkan, bahkan banyak sekali kosa kata bahasa Arab yang sudah diadopsi menjadi bahasa Indonesia.

Di sisi lain, sebelum majunya bangsa Eropa, ilmu pengetahun maju pesat di dunia Arab, dan literaturnya masih sangat dibutuhkan sampai saat ini. Sehingga kebutuhan pembelajaran bahasa Arab menjadi penting adanya untuk menunjang kesempurnaan ibadah umat muslim, menggali khazanah keilmuan masa lampau, juga sebagai media komunikasi internasional bagi para pekerja di Negara-negara Arab yang memang sangat banyak berasal dari Indonesia.

Walaupun demikian pentingnya bahasa Arab, tidak semua orang mendapatkan kesempatan untuk mempelajarinya, pada umumnya pelajaran bahasa Arab yang didapatkan hanya pada sekolah yang berbasis agama saja dan dalam porsi yang terbatas, yaitu hanya mendapatkan jumlah jam yang tersisa dari jam mata pelajaran umum, ditambah lagi sangat jarang didukung oleh lembaga kursus sebagaimana bahasa Inggris. Dengan kesempatan yang terbatas ini, maka banyak kendala yang siswa hadapi dalam proses pembelajarannya.

SMA Terpadu Al-Ma'shum Mardiyah Cianjur sebagai sekolah yang berbasis agama dan menggunakan sistem boarding school dalam pengelolaan pendidikannya, memasukkan pelajaran bahasa Arab ini ke dalam mata pelajaran inti khas Sekolah, sehingga keberadaannya sangatlah penting mengingat visi yang dibangun oleh sekolah atas arahan Ketua Pengurus Yayasan Al- 
Ma'shum Mardiyah, Umay M Dja'far Shiddieq dalam bukunya berbunyi:

"terbentuknya generasi muslim yang kuat aqidah, taat syari'ah, mulia akhlak, afiat jiwa raga, mampu berbahasa Arab dan Inggris, serta menguasai dasar-dasar ilmu pengetahuan dan teknologi berlandaskan alQur'an" (Shiddieq, et.al., 2015). Dan termuat secara rinci dalam misi Sekolah sebagai berikut: "memberikan pemahaman kepada siswa tentang pentingnya bahasa Arab dan Inggris" dan "membiasakan siswa untuk berkomunikasi menggunakan bahasa Arab dan Inggris dengan benar dan baik" (Ibid).

Dengan dimasukkannya keterampilan berbahasa Arab ke dalam Visi dan Misi Sekolah meniscayakan adanya penekanan terhadap mata pelajaran terkait, sehingga porsi pelajaran Bahasa Arab menjadi banyak, selain pelajaran bahasa Arab itu sendiri, didukung pula oleh pelajaran lainnya dalam bidang gramatika bahasa Arab seperti Nahwu dan Sharaf, belum lagi terdapat program-program di luar jam sekolah, seperti penguatan bahasa asing selama siswa berada di Asrama, Masjid dan lingkungan pesantren dengan program English and Arabic Day, al-Muhaadatsah atau Conversation, i'thoul mufrodaat dan lain lain.

Namun ternyata dengan banyaknya program pendukung tersebut di atas belum cukup untuk menjadikan bahasa Arab sebagai bahasa yang digunakan dalam percakapan sehari-hari terlebih menjadikan bahasa Arab menjadi bahasa tulisan dalam mengungkapkan gagasan.

Sebagaimana diketahui bahwa dalam pembelajaran bahasa Arab ada empat keterampilan yang harus dikuasai, yaitu menyimak (mahārat istimā), berbicara (mahārat kalām) membaca (mahārat qirā'at) dan menulis (mahārat kitābat). Menyimak dan berbicara adalah dua keterampilan yang berkaitan dengan penggunaan bahasa Arab dalam ranah lisan sedangkan membaca dan menulis adalah dua keterampilan yang berkaitan dengan penggunaan bahasa Arab dalam ranah tulisan.

Berdasarkan pengalaman peneliti dan pengamatan sementara pada proses pembelajaran di SMA Terpadu Al-Ma'shum Mardiyah Cianjur, dari keempat keterampilan di atas, ada dua keterampilan yang dianggap paling sulit bagi siswa yaitu keterampilan berbicara dan menulis, jika dibandingkan dengan keterampilan menyimak dan membaca.

Pada keterampilan berbicara bahasa Arab, seringkali siswa mengalami kesulitan dalam mengungkapkan ide secara lisan, menggunakan symbol-simbol kata dalam bahasa arab, dan kurang percaya diri untuk menggunakan bahasa Arab dalam percakapan sehari-hari karena ketakutan akan kesalahan kata dan ucap secara gramatika bahasanya, kurang percaya diri dan kurangnya motivasi untuk mau bisa berbicara bahasa Arab.

Pada keterampilan menulis, adakalanya masih banyak kesalahan pada text yang mereka tulis atau mengucapkannya, mulai pemilihan katakata, tata bahasa yang tidak sesuai dengan aturan penulisan, sampai pada makna yang sulit dipahami bagi pembaca. Itu semua karena rendahnya kreativitas yang siswa miliki dan juga pengetahuan menulis bahasa bukan bahasa yang mereka gunakan seharihari. Kreativitas siswa yang rendah menyebabkan mereka tidak tertarik terhadap kegiatan menulis yang juga berakibat pada aktivitas yang membosankan, karena kurangnya pengetahuan dalam proses menulis. 
Beberapa permasalahan yang kongkret yang dihadapi oleh siswa khususnya pada proses pembelajaran berbicara dan menulis di kelas adalah sebagai berikut :

1. Ketika siswa memulai untuk berbicara dan menulis paragraf, mereka kurang bisa mengkaitkan gagasan yang ada yang berakibat pada lemahnya kemampuan percakapan dan menulis text dari sudut uniti dan koherensi.

2. Siswa masih lemah dalam pengorganisasian informasi ke dalam teks yang akurat dan penggunakan symbol tulisan yang tidak tepat baik hasil text yang mereka tulis ataupun ketika berbicara akan sulit dipahami oleh pembaca.

3. Kebanyakan siswa masih miskin ide dan imaginasi untuk dikembangkan ke dalam tulisan maupun berbicara.

4. Motivasi yang rendah seperti rendahnya kesadaran akan kewajiban belajar siswa, kurang aktif dalam mengikuti proses pembelajaran, kurang antusias dalam mempelajari bahasa Arab, kurang adanya usaha untuk mengerjakan tugas secara mandiri, serta kondisi lingkungan belajar yang kurang kondusif.

Permasalahan tersebut berimplikasi kepada nilai ulangan siswa, dimana rata-rata pencapaian nilai siswa pada ulangan semesteran masih banyak yang di bawah standar Kriteria Ketuntasan Minimal (KKM) yang ditetapkan guru dan Sekolah yaitu 75 , sebagaimana terlihat jelas dari data nilai ulangan semester yang peneliti dapatkan dari Guru Bahasa Arab selama dua tahun terakhir sebagai berikut:

a.Rekap Nilai Keterampilan al-Kalam

1. Tahun Pelajaran 2013-2014 semester 1 dengan rata-rata 67,19 , dan pada semester 2 dengan rata-rata 68,93.
2. Tahun Pelajaran 2014-2015 semester 1 dengan rata-rata 72,17 , dan pada semester 2 dengan rata-rata73,96, kesemuanya di bawah KKM 75.

b. Rekap Nilai Keterampilan al-Kitabah

1. Tahun Pelajaran 2013-2014 semester 1 dengan rata-rata 69,15 dan semester 2 dengan rata-rata 70.

2. Tahun Pelajaran 2014-2015 semester 1 dengan rata-rata 69,41, dan semester 2 dengan rata-rata 69,46, juga semuanya di bawah KKM 75.

Berdasarkan hasil wawancara terhadap siswa kelas X SMA Terpadu Al-Ma'shum Mardiyah Cianjur, ditemukan bahwa faktor kepercayaan diri yang menghambat peserta didik untuk menuangkan ide-ide yang ada dalam bentuk tulisan. Kepercayaan diri itu diantaranya karena kurang menguasai kosa kata dan kurang memahami struktur bahasanya. Selain itu model yang digunakan guru cenderung membosankan.

Sementara hasil wawancara dengan guru, terdapat keluhan dalam menghadapi siswa yang sangat heterogen tingkat kemampuan dalam pelajaran bahasa Arab mengingat siswa kelas $X$ ada yang lulusan SMP berbasis agama dengan pelajaran bahasa Arab cukup dan ada juga lulusan SMP umum yang tidak pernah belajar bahasa Arab. Juga model pembelajaran yang dirasa masih kesulitan menemukan yang tepat untuk pembelajaran bahasa Arab.

Menurut hemat peneliti, kesemua persoalan di atas bermuara pada guru dan cara mengajarnya, mulai dari metode dan model pembelajaran yang konvensional seperti ceramah, tidak banyak melibatkan siswa dalam proses pembelajaran, kurangnya interaksi antara guru dengan siswa ataupun siswa dengan sisawa lainnya selama proses pembelajaran di kelas seperti 
dalam mengemukakan gagasan, mengajukan pertanyaan dan menjawab pertanyaan sehingga proses belajar mengajar kurang optimal, kurang kreatif dan inovatif serta terbatasnya media yang digunakan menjadi penyebab utama siswa sulit mengerti dan enggan mengikuti pelajaran Bahasa Arab. Oleh karena itu sudah saatnya guru mulai menggunakan metode dan model pembelajaran yang lebih variatif dan inovatif dalam proses pembelajarannya sehingga hasil belajar siswa dapat terus meningkat.

Sebagaimana yang diungkapkan oleh Barnawi dan Mohammad Arifin bahwa pembelajaran yang berkualitas hanya dapat diwujudkan oleh guru yang memiliki kemampuan unggul dan motivasi tinggi dalam melaksanakan kewajibannya, yaitu guru yang melaksanakan tugas pokoknya dengan baik sebagaimana termaktub dalam Undang-Undang Nomor 14 Tahun 2005 tentang Guru dan Dosen, yaitu merencanakan pembelajaran, melaksanakan pembelajaran, menilai hasil pembelajaran, membimbing dan melatih peserta didik, serta melaksanakan tugas tambahan (Barnawi \& Arifin, 2012).

Guru juga dituntut untuk bekerja dengan kualitas tinggi dalam menjalankan tugas-tugas berikut: 1 ) bekerja dengan siswa secara individual, 2) persiapan dan perencanaan pembelajaran, 3) pendayagunaan media pembelajaran, 4) melibatkan siswa dalam berbagai pengalaman belajar, dan 5) kepemimpinan yang aktif dari guru (Barnawi \& Arifin, 2012). Dan guru juga harus mampu mengelola pembelajaran di kelas yang mengarah pada kepentingan siswa, bukan kepentingan guru semata (Thoifuri, 2013).

Tidak berlebihan jika persoalan siswa ada di tangan guru dalam penanganannya, karena guru adalah orang yang selalu memberi pengaruh secara abadi, tapi ia tidak mau tahu kapan pengaruh itu berhenti. Guru merupakan sosok manusia pewaris dan penerus berkembangnya ilmu pengetahuan dan teknologi. Guru adalah mitra belajar siswa dengan tanpa syarat. Guru merupakan pribadi utuh untuk merubah perilaku dan kepribadian peserta didik. Guru adalah manusia yang memikul beban penderitaan siswa dalam belajar. Guru merupakan seseorang yang mampu memprediksi sesuatu yang akan terjadi. Guru adalah bentuk manusia yang mampu menyelesaikan problematika sosial anak didik. Guru adalah sosok manusia yang berpegang pada prinsip jika melihat ia tahu, jika mendengar ia hafal dan jika melakukan ia paham. Dan guru adalah figure menusia yang mampu melihat realitas alam untuk anak didiknya (Thoifuri, 2013)

Berdasarkan uraian di atas, maka terdapat beberapa kesenjangan antara harapan dan kenyataan yang ada. Untuk menghilangkan kesenjangan itu harus ada usaha yang efektif agar proses pembelajaran menjadi berkualitas, mampu meningkatkan antusiasme siswa dalam belajar bahasa Arab dengan baik sehingga tercapai tujuan pembelajaran yang diharapkan. Proses pembelajaran yang dilakukan dengan pengelolaan pembelajaran yang menggunakan model-model pembelajaran yang tepat dengan melibatkan siswa secara langsung dapat menghasilkan pembelajaran yang optimal sehingga meningkatkan hasil belajar bahasa Arab siswa.

Alternatif solusi yang diharapkan dapat meningkatkan hasil belajar Bahasa Arab kuhususnya keterampilan berbicara dan menulis arab siswa kelas X SMA Terpadu alMa'shum Mardiyah Cianjur adalah dengan menggunakan model pembelajaran kooperatif STAD (Student Teams 
Achievement Divisions) dan TPS (Think-PairSquare) sehingga siswa akan lebih antusias terlibat aktif dalam pembelajaran dan mendapat pengalaman pembelajaran baik secara individu maupun kelompok yang akan meningkatkan kemampuan akademisnya.

Untuk membuktikan alternatif solusi tersebut mampu meningkatkan kemampuan hasil belajar Bahasa Inggris siswa maka dilakukan suatu Penelitian Tindakan Kelas (PTK) sebagaimana salah satu tujuan PTK adalah untuk meningkatkan proses dan hasil belajar dan bersikap kritis terhadap hasil belajarnya (Zainal, et.al., 2015)

Penelitian ini menggunakan model pembelajaran Student Teams Achievement Divisions (STAD) dan Think-Pair-Square (TPS) sebagai media pembelajaran untuk mengajarkan keterampilan berbicara dan menulis. Dengan menggunakan model ini diharapkan akan merangsang otak siswa untuk lebih aktif dan berani dalam berbicara serta untuk lebih kreatif dalam menulis. Siswa dapat lebih tertarik dengan mudah mempelajari dan memahami sebuah cerita atau topik untuk menulis dan menceritakan kembali atau bercerita dalam bahasa Arab dengan mudah

Berdasarkan latar belakang permasalahan di atas, maka rumusan permasalahan yang diajukan dalam proposal penelitian ini adalah :

1. Apakah melalui penggunaan model pembelajaran Student Teams Achievement Divisions (STAD) dan ThinkPair-Square (TPS) dapat meningkatkan hasil belajar bahasa Arab pada keterampilan berbicara dan menulis pada siswa kelas X SMA Terpadu alMa'shum Mardiyah Cianjur?

2. Bagaimana pengelolaan pembelajaran dengan model Student Teams Achievement Divisions (STAD) dan Think-
Pair-Square (TPS) dapat meningkatkan hasil belajar bahasa Arab pada keterampilan berbicara dan menulis pada siswa kelas X SMA Terpadu alMa'shum Mardiyah Cianjur?

\section{METODE}

Metode penelitian yang digunakan adalah Penelitian Tindakan Kelas (PTK) dengan model pembelajaran kooperatif STAD dan TPS dilaksanakan melalui dua siklus yang berkesinambungan. Setiap siklusnya terdiri dari dua pertemuan untuk tatap muka dan observasi hasil belajar ranah psikomotor dan menggunakan teknik validasi ahli (expert judgedment).

Penelitian ini dimulai pada tanggal 6 Oktober sampai dengan tanggal 16 Oktober 2015. Penelitian dilakukan di kelas X.3 SMA Terpadu al-Ma'shum Mardiyah Cianjur dengan 22 siswa, tahun pelajaran 20152016.

Data yang akan dikumpulkan melalui penelitian ini meliputi data hasil belajar Psikomotor, aktivitas siswa dalam bentuk on/off task, tanggapan / respon siswa dan guru terhadap pembelajaran yang telah dilakukan, dan aktivitas guru selama kegiatan pembelajaran berlangsung.

\section{HASIL DAN PEMBAHASAN}

\section{A. Antusiasme Belajar Siswa}

Antusias belajar diukur berdasarkan hasil pengamatan aktivitas siswa selama proses pembelajaran. Aktivitas on task artinya siswa melakukan sktivitas yang relevan dengan kegiatan pembelajaran, sedangkan off task artinya siswa melakukan aktivitas yang tidak relevan dengan kegiatan pembelajaran, seperti mengobrol, jalanjalan, melamun, usil, mengantuk, dan melakukan pekerjaan lain. 
Berdasarkan data yang diperoleh dari siklus 1 dan 2 menemukan bahwa hasil pengamatan aktifitas/antusiame siswa pada siklus 1 dan 2 yang diamati oleh observer selama 4 pertemuan dalam 2 siklus dihasilkan nilai secara rinci yang divisualisasikan pada tabel dan grafik di bawah ini:

Tabel 1. Persentase On dan Off Task

\begin{tabular}{ccccc}
\hline Siklus & \multicolumn{2}{c}{ Tindakan 1 } & \multicolumn{2}{c}{ Tindakan 2 } \\
\cline { 2 - 5 } & $\begin{array}{c}\text { Off } \\
\text { task }\end{array}$ & $\begin{array}{c}\text { On } \\
\text { task }\end{array}$ & $\begin{array}{c}\text { Off } \\
\text { task }\end{array}$ & $\begin{array}{c}\text { On } \\
\text { task }\end{array}$ \\
\hline $\mathbf{1}$ & 7,39 & 92,61 & 7,95 & 92,05 \\
\hline $\mathbf{2}$ & 7,39 & 92,61 & 6,82 & 93,18 \\
\hline
\end{tabular}

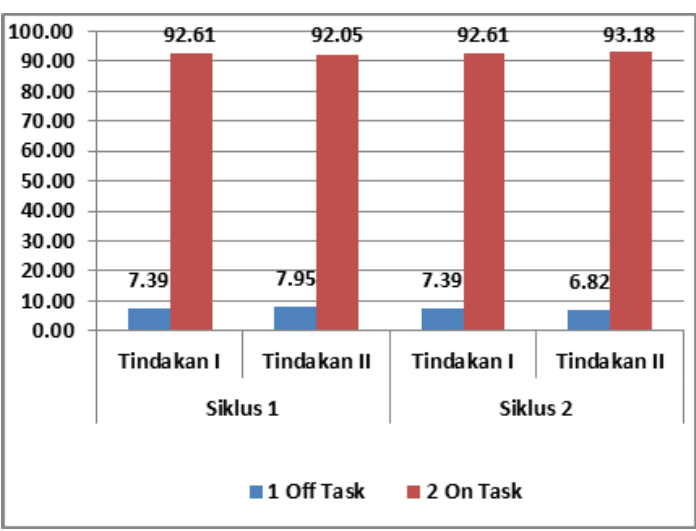

Gambar 1. Antusiasme Belajar Siswa

Rekapitulasi hasil observasi terhadap antusias belajar siswa menunjukkan bahwa pada setiap tindakan baik siklus I maupun siklus II, sebagian besar siswa bersemangat dan terlibat secara aktif mengikuti kegiatan pembelajaran, hal ini ditunjukkan dengan angka presentase on task yang masuk dalam kategori sangat tinggi, yaitu berada pada rentang $80-100$. Siswa banyak menunjukkan sikap positif terhadap kegiatan pembelajaran daripada sikap yang negatif yang tentu saja akan merugikan diri mereka sendiri.
Menurut Rusman, konsep utama dari belajar kooperatif (Cooperative Learning) adalah teknik pengelompokkan yang di dalamnya siswa bekerja terarah pada tujuan belajar bersama dalam kelompok kecil yang umumnya terdiri dari 4 orang siswa. Belajar Cooperative Learning adalah pemanfaatan kelompok kecil dalam pembelajaran yang memungkinkan siswa bekerja bersama untuk memaksimalkan belajar mereka dan belajar anggota lainnya dalam kelompok tersebut (Rusman, 2012)

Menurut pendapat Slavin yang dikutip oleh Trianto (2010), konsep utama dari belajar Kooperatif adalah :

a. Penghargaan kelompok, yang akan diberikan jika kelompok mencapai kriteria yang ditentukan.

b. Tanggung jawab individual, bermakna bahwa suksesnya kelompok tergantung pada belajar individual semua anggota kelompok. Tanggung jawab ini terfokus dalam usaha untuk membantu yang lain dan memastikan setiap anggota kelompok telah siap menghadapi evaluasi tanpa bantuan yang lain.

c. Kesempatan yang sama untuk sukses, bermakna bahwa siswa telah membantu kelompok dengan cara meningkatkan belajar mereka sendiri. Hal ini memastikan bahwa setiap siswa dengan kemampuan yang berbeda sama-sama tertantang untuk melakukan yang terbaik dan bahwa semua anggota kelompok sangat bernilai.

STAD merupakan model pembelajaran kooperatif yang menerapkan tiga konsep yang penting bagi semua metode kelompok belajar siswa; penghargaan kelompok, tanggung jawab perorangan, dan kesempatan yang sama untuk memperoleh keberhasilan. Dengan kemampuan yang berbeda itu akan membuat siswa menjadi 
tertantang untuk melakukan yang terbaik dan semua anggota kelompok menjadi sangat bernilai, siswa akan menjadi lebih antusias dan aktif baik secara fisik maupun psikis dalam kegiatan belajar mengajar. Demikian juga dengan model pembelajaran TPS yang sangat menguntungkan siswa dalam mencapai keberhasilan dalam kerja kelompok. Hal ini dapat dilihat dari angka presentase on task yang sangat tinggi. Kenaikan presentase on task juga terjadi dari siklus I hingga siklus II.

Dari uraian di atas dapat di ambil kesimpulan bahwa model pembelajaran kooperatif STAD dan TPS dalam pembelajaran bahasa Arab dapat meningkatkan antusias belajar siswa sehingga siswa terlibat aktif secara fisik dan psikis dalam proses kegiatan belajar mengajar.

\section{B. Hasil Belajar al-Kitabah}

Secara keseluruhan, terdapat peningkatan yang cukup signifikan pada nilai belajar al-kitabah dari siklus 1 ke siklus 2, dimana rata-rata nilai pada siklus 1 sebesar 81,0 meningkat pada siklus 2 sebesar 84,8 , artinya terdapat peningkatan sebesar 3,8 poin, demikian juga terjadi peningkatan pada peraih nilai tertinggi, dimana pada siklus 1 nilai tertinggi sebesar 92,5 dan pada siklus 2 sebesar 95,0, dengan tingkat ketuntasannya (persentase yang meraih nilai di atas KKM) meningkat dari 77,3 \% pada siklus 1 menjadi $81,8 \%$ pada siklus 2., rincian data ini dapat dilihat pada tabel 2 .

Menurut lan Reece dan Stephen Walker pembelajaran pada ranah psikomotor meliputi aspek psiko (aspek kognitif yang harus diingat dan dimengerti) dan aspek motor (aspek gerakan dan koordinasi antara otak dan anggota badan) (Reece \& Walker, 1997)
Tabel 2. Rekapitulasi Hasil Belajar al-Kitabah Siklus I dan II

\begin{tabular}{lcc}
\hline \multirow{2}{*}{ Hasil } & \multicolumn{2}{c}{ Al-Kitabah } \\
\cline { 2 - 3 } Rekatulasi & Siklus 1 & Siklus 2 \\
\hline Rata-rata & 81.0 & 84.8 \\
\hline Nilai Tertinggi & 92.5 & 95.0 \\
\hline Nilai Terendah & 60.0 & 70.0 \\
\hline Nilai di Atas KKM & $77.3 \%$ & 81.8 \\
\hline $\begin{array}{l}\text { Nilai di Bawah } \\
\text { KKM }\end{array}$ & 22.7 & 18.2 \\
\hline
\end{tabular}

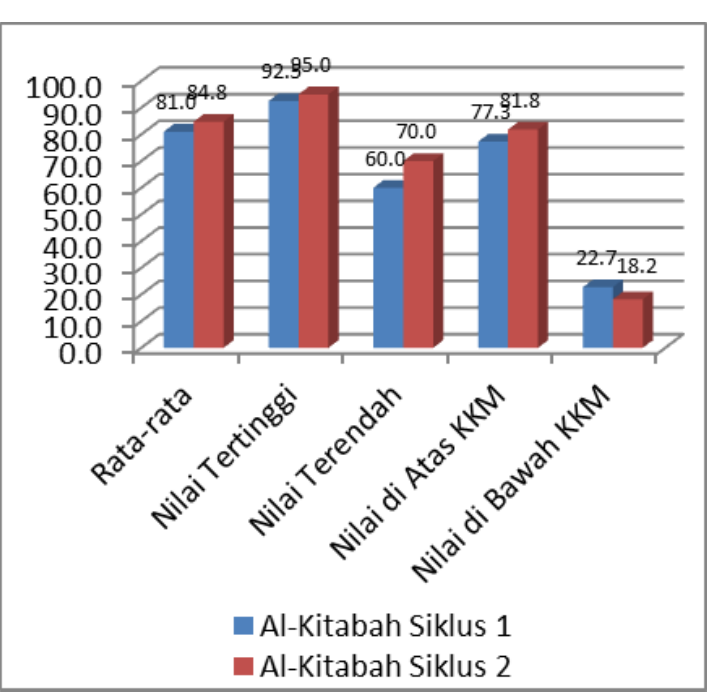

Gambar 2. Hasil Belajar al-Kitabah

Muhlisin (2012) menyatakan bahwa model pembelajaran kooperatif STAD (Student Teams Achievement Divisions) memiliki beberapa kelebihan yang tidak dimiliki oleh model pembelajaran lain (1). Siswa bekerja sama dalam mencapai tujuan dengan menjunjung tinggi norma-norma kelompok. (2). Siswa aktif membantu dan memotivasi semangat untuk berhasil bersama. (3). Aktif berperan sebagai tutor sebaya untuk lebih meningkatkan keberhasilan kelompok. (4). Pemberian kuis setelah satu sampai dua periode penyajian, guru dan latihan kelompok siswa mengikuti 
kuis secara individu, hal ini bertujuan untuk menunjukkan apa saja yang telah diperoleh siswa setelah belajar dalam kelompok.

Siswa bekerja sama dalam mencapai tujuan dengan menjunjung tinggi normanorma kelompok adalah keungulan STAD yang digunakan dalam penelitian ini sehingga membuat sesama siswa berinteraksi di dalam yang mengakibatkan peningkatan keterampilan al-kitabah akibatnya berdampak pada hasil belajar keterampilan al-kitabah.

C. Hasil Belajar Al-Kalam Siklus I dan II

Secara keseluruhan, terdapat peningkatan nilai belajar al-kalam dari siklus 1 ke siklus 2, dimana rata-rata nilai pada siklus 1 sebesar 80,7 meningkat pada siklus 2 sebesar 81,7 , artinya terdapat peningkatan sebesar 1,0 poin, walaupun tidak tidak terjadi peningkatan pada peraih nilai tertinggi, dimana pada siklus 1 nilai tertinggi sebesar 92,0 dan pada siklus 2 sebesar 92,0 juga, akan tetapi terjadi peningkatan yang cukup signifikan pada tingkat ketuntasannya (persentase nilai di atas KKM) yaitu dari 68,2 $\%$ pada siklus 1 menjadi $72,7 \%$ pada siklus 2., rincian data ini dapat dilihat pada tabel 3 berikut.

Tabel 4. Rekapitulasi Hasil Belajar al-Kalam Siklus I dan II

\begin{tabular}{lcc}
\hline \multirow{2}{*}{ Hasil Rekapitulasi } & \multicolumn{2}{c}{ Al Kalam } \\
\cline { 2 - 3 } & Siklus 1 & Siklus 2 \\
\hline Rata-rata & 80.7 & 81.7 \\
\hline Nilai Tertinggi & 92.0 & 92.0 \\
\hline Nilai Terendah & 68.0 & 70.0 \\
\hline Nilai di Atas KKM & $68.2 \%$ & $72.7 \%$ \\
\hline Nilai di Bawah KKM & $31.8 \%$ & $27.3 \%$ \\
\hline
\end{tabular}

Keunggulan model pembelajaran kooperatif adalah (1). Siswa lebih banyak berdiskusi, baik pada saat berpasangan, dalam kelompok berempat, maupun dalam diskusi kelas, sehingga akan lebih banyak ide yang dikeluarkan siswa dan akan lebih mudah dalam merekonstrusi pengetahuannya, (2). Setiap siswa akan mendapatkan kesempatan untuk berdiskusi dengan siswa yang lebih pintar, ataupun dengan siswa yang lebih lemah, (3). Dominasi guru dalam pembelajaran semakin berkurang. Guru hanya berperan sebagai fasilitator dan motivator bagi siswa untuk berusaha mengerjakan tugas dengan baik.

Menurut Sharan (2012), Think-PairSquare memberi waktu berpikir kepada siswa. Waktu tunggu yang digunakan dalam fase berpikir itu penting. Jika al-insya diberikan selama pelajaran berlangsung banyak siswa yang tidak punya waktu untuk memperthatikan dan memikirkan apa yang terjadi. Pemikiran dan artikulasi digunakan untuk membantu siswa memahaminya. Slavin (2008) menyatakan Think-Pair-Square memiliki prosedur yang ditetapkan secara eksplisit untuk memberi sisiwa waktu lebih banyak untuk berpikir, menjawab dan saling membantu satu sama lain.

Melalui model pembelajaran ini, guru memberikan kesempatan yang sama kepada siswa untuk berpartisipasi dalam kelompok dan mempengaruhi siswa dalam meningkatkan prestasi belajarnya, terutama dalam meningkatkan keterampilan berbicara akibatnya hasil belajar keterampilan al-kalam meningkat.

Dari semua kajian teori-teori dan datadata yang diambil selama penelitian ini, maka dapat ditarik sebuah kesimpulan bahwa model pembelajaran STAD dan TPS dapat meningkatkan hasil belajar siswa dalam bahasa Arab yang meliputi keterampilan al-kalam dan al-kitabah. 


\section{PENUTUP}

Berdasarkan hasil analisis data, temuan penelitian, dan refleksi setiap siklus, maka Penelitian Tindakan Kelas (PTK) dengan mengimplementasikan model pembelajaran kooperatif STAD dan TPS pada pembelajaran Bahasa Arab menghasilkan kesimpulan sebagai berikut:

Pengelolaan pembelajaran dengan model pembelajaran kooperatif STAD dan TPS dapat meningkatkan hasil belajar bahasa Arab siswa kelas X.3 SMA Terpadu AlMa'shum Mardiyah Cianjur. Hal ini dapat dibuktikan dengan hasil yang didapat selama melakukan penelitian tindakan kelas dengan terpenuhinya kriteria keberhasilan PTK dan mengalami peningkatan dari siklus I ke siklus II. Presentase ketuntasan klasikal hasil belajar al-kitabah naik dari $77,3 \%$ menjadi $81,8 \%$, dengan nilai rata-ratanya naik dari 81,0 menjadi 84,8 . Sementara hasil belajar al-kalam, persentase ketuntasan klasikalnya naik dari $68,2 \%$ menjadi $72,7 \%$, dengan nilai rata-rata naik dari 80,7 menjadi 81,7.

Pengelolaan pembelajaran dengan model pembelajaran kooperatif STAD dan TPS dalam kegiatan pembelajaran mampu meningkatkan antusias siswa untuk terlibat secara aktif dalam pembelajaran baik secara fisik maupun psikis, meningkatkan komitmen siswa, menumbuhkan daya saing secara sehat, meningkatkan kemampuan berkomunikasi untuk menyampaikan informasi, ide dan pendapat, serta meningkatkan kemampuan akademis baik individu maupun kelompok yang akhirnya dapat meningkatkan hasil belajar siswa

\section{DAFTAR PUSTAKA}

Barnawi \& Arifin, M. (2012). Kinerja Guru Profesional; Instrumen Pembinaan, Peningkatan dan Penilaian. Jogjakarta: Ar-Ruzz Media.
Dimyati, M. (2006). Belajar dan Pembelajaran. Jakarta: Rineka Cipta. Hermawan, A. (2011). Metodologi Pembelajaran Bahasa Arab. Bandung: PT Remaja Rosdakarya

Huda, M. (2013). Model-Model Pengajaran dan Pembelajaran; Isu-Isu Metodis dan Pragmatis. Yogyakarta: Pustaka Pelajar.

Isjoni. (2009). Pembelajaran KooperatifnMeningkatkan Kecerdasan Komunikasi Antar Pesertan Didik. Yogyakarta: Pustaka Pelajar

Kesuma, A.T. (2013). Menyusun PTK itu gambang. Bandung: Erlangga

Lie, A. (2008). Cooperative Learning. Jakarta: Grasindo.

Millis, B.J \& Cottell, P.G. (1998). Cooperative Learning for Higher Education Faculty. Americal Council on Education. The Oryx Press, Phoenix, AZ, 1998, http://www.wcer.wise.edu/archieve/cll/cl/doi $\mathrm{ng} \mathrm{cl} /$ thinksq.html

Muhlisin, A. (2012). Pengembangan Perangkat Pembelajaran IPA Terpadu Berbasis Contextual Teaching and Learning (CTL) dengan Model Pembelajaran STAD. Journal of Educational Research and Evaluation 1 (2)

Ngalimun. (2013). Strategi dan Model Pembelajaran., Yogyakarta: Aswaja Pressindo

Retnowati, R. (2008). Metodologi Penelitian. Program Pascasarjana Universitas Pakuan: Tidak Diterbitkan

Richards, J.C \& Reanndya, W.A. (2002). Methodology in Language Teaching. Cambridge: Cambridge University Press

Robbins, S \& Judge, T. (2010). Organizational Behavior. England: Pearson

Robert E.W-B \& Kagan, S. (1992). About Cooperative Learning. San Antonio: University of Texax at San Antonio

Sagala, S. (2006). Administrasi Pendidikan Kontemporer. Bandung: CV Alfabeta

Sadulloh, U. (2010). Pedagogik (Ilmu Mendidik). Bandung: Alfabeta

Sani, R.A. (2013). Inovasi Pembelajaran. Jakarta: Bumi Aksara..Sa'ud, U.S (2008). Inovasi Pendidikan. Bandung: Alfabeta

Sedarmayanti. (2011). Membangun Dan Mengembangkan Kepemimpinan Serta Meningkatkan Kinerja Untuk Meraih Keberhasilan. Bandung: PT Refika Aditama 
Shambaugh, N \& Magliaro, S.G. (2006). Instructional Design. Boston: Pearson Education,Slameto. (2010). Belajar \& Faktor-Faktor Yang Menpengaruhinya. Jakarta: Rineka Cipta

Sharan, S. (2012). Cooperative Learning, terjemahan Sigit Prawoto. Yogyakarta: FamiliaSlavin, R.E. (2008). Cooperative Learning Teori,Riset dan Praktik. Bandung: Nusa MediaSomantri, A dan Muhidin, S. (2006). Aplikasi Statistika dalam Penelitian. Bandung: CV Pustaka Setia.

Siregar, E \& Nara, H. (2002). Teori dan Pembelajaran, Ghalia Indonesia

Solahudin, M. (2011). Quantum Speaking. Yogyakarta: Imortal Publisher,

Solahudin, M. (2013). Tutorial Writing Bahasa Inggris. Yogyakarta: Berlian.

Sugiyono. (2013). Metode Penelitian Pendidikan; Pendekatan Kuantitatif, Kualitatif, $R$ \& $D$. Bandung: Alfabeta

Suherdi, D. (2007). Bahan Ajar PLPG Bahasa Inggris, Universitas Pendidikan Indonesia

Suprijono, A. (2010). Cooperative Learning Teori \& Aplikasi Paikem. Yogyakarta: Pustaka Pelajar

Trianto \& Tutik. (2007). Sertifikasi Guru dan Upaya Peningkatan Kualifikasi Kompetensi dan Kesejahteraan. Jakarta: Prestasi Pustaka 